\title{
Peningkatan Hasil Belajar Peserta Didik dalam Pembelajaran Tematik Terpadu Menggunakan Model Problem Based Learning (PBL)di Kelas V SDN 15 Koto Kabun Kabupaten Pesisir Selatan
}

\author{
Yuci Yefrika1, Elvia Sukma², Tri Susilawati ${ }^{3}$ \\ ${ }^{1}$ Program Studi Pendidikan Guru Sekolah Dasar, Universitas Negeri Padang \\ ${ }^{2}$ Program Studi Pendidikan Guru Sekolah Dasar, Universitas Negeri Padang \\ ${ }^{3}$ SDN 15 Koto Kabun, Pesisir Selatan \\ e-mail: 1yyefrika@gmail.com, ${ }^{2}$ elfiasukma105@gmail.com, ${ }^{3}$ trisusilawati197@gmail.com
}

\begin{abstract}
Abstrak
Penelitian ini dilatarbelakangi oleh guru yang terlalu mendominasi dalam proses pembelajaran serta kurang menerapkan model-model inovatif yang berbasis kelompok dalam meningkatkan hasil belajar peserta didik. Penelitian ini bertujuan untuk mendeskripsikan peningkatan hasil belajar peserta didik pada pembelajaran tematik terpadu di kelas $V$ Tema 8 Lingkungan Sahabat Kita menggunakan metode Problem Based Learning. Jenis penelitian yaitu Penelitian Tindakan Kelas (PTK) menggunakan pendekatan kualitatif dan kuantitatif. Penelitian dilaksanakan sebanyak dua siklus. Rancangan penelitian meliputi perencanaan, pelaksanaan, pengamatan dan refleksi. Subjek penelitian adalah guru dan 30 orang peserta didik kelas $\mathrm{V}$ SDN 15 Koto Kabun, Pesisir Selatan. Teknik pengumpulan data melalui observasi, tes dan penilaian RPP. Hasil penelitian pengamatan RPP siklus I memperoleh rata-rata $87,49 \%$ dengan kategori baik (B) meningkat pada siklus II menjadi 96,42 kategori amat baik (AB). Pelaksanaan pada aspek guru siklus I memperoleh rata-rata $76,78 \%$ dengan kategori cukup (C) meningkat pada siklus II yaitu 92,85\% dengan kategori amat baik (AB). Pelaksanaan pada aspek peserta didik siklus I memperoleh ratarata $76,78 \%$ dengan kategori cukup (C) meningkat pada siklus II yaitu 92,85\% dengan kategori amat baik $(A B)$. Hasil belajar siswa siklus I memperoleh rata-rata nilai 74,19 dengan kategori baik (B) meningkat pada siklus II 88,06 dengan kategori sangat baik (SB). Dengan demikian model Problem Based Learning dapat meningkatkan hasil belajar peserta didik pada pembelajaran tematik terpadu di kelas V SDN 15 Koto Kabun, Pesisir Selatan.
\end{abstract}

Kata kunci: Pembelajaran tematik terpadu Model problem based learning

\begin{abstract}
This research was based on teachers who are too dominating in learning process and lack of innovative models group-based in improving student learning outcomes. This study aims to describe the improvement of students' learning outcomes in integrated thematic in grade V Tema 8 "Our Friend Environment" by using problem based learning method. This research was a Class Action Research (PTK) using qualitative and quantitative approach. The research was conducted in two cycles. The research design included planning, implementation, observation and reflection. The subjects of the study were teachers and 30 students of grade V SDN 15 Koto Kabun, Pesisir Selatan. The data collection was through observation, tests and RPP assessment. The results of the first cycle lesson plan observation has an average of $87.49 \%$ with a good category (B) increasing in cycle II to 96.42 with a very good category (AB). Implementation on the teacher aspect of cycle I has an average of $76.78 \%$ with a average category $(C)$ increasing in cycle II which is $92.85 \%$ with a very good category (AB). Implementation in the aspect of learners cycle I has an average of $76.78 \%$ with a average category $(C)$ increasing in cycle II of $92.85 \%$ with a very good category $(A B)$. Student learning outcomes cycle I earns an average of 74.19 with a
\end{abstract}


good category (B) increasing in cycle II of 88.06 with a very good category (SB). Thus the Problem-Based-Learning model can improve students' learning outcomes in integrated thematic at grade V SDN 15 Koto Kabun, Pesisir Selatan.

\section{Keywords : Integrated thematic learning Problem based learning}

\section{PENDAHULUAN}

Pengelolaan kegiatan pembelajaran di Sekolah Dasar dilakukan dengan menggunakan pendekatan pembelajaran tematik terpadu. Hal ini tercantum dalam Peraturan Menteri Pendidikan dan Kebudayaan Nomor 57 Tahun 2014 tentang kurikulum 2013 Sekolah Dasar menyatakan "pelaksanaan pembelajaran di Sekolah dasar dilakukan dengan pendekatan tematik terpadu".Menurut Majid (2014:80) mengemukakan bahwa "Pembelajaran tematik terpadu adalah pembelajaran yang terpadu yang menggunakan tema untuk mengaitkan beberapa mata pelajaran sehingga dapat memberikan pengalaman yang bermakna kepada murid". Selain itu, menurut Yarsina (2016) dalam jurnalnya, pembelajaran tematik terpadu merupakan pendekatan pembelajaran yang mengarahkan peserta didik untuk terlibat secara langsung dalam pengalaman bermakna dimana dalam penyajian pembelajarannya melibatkan beberapamatapelajaran. Dikatakan bermakna karena dalam pembelajaran tematik, peserta didik akan memahami konsep-konsep yang mereka pelajari melalui pengalaman langsung dan menghubungkannya dengan pengalaman peserta didik di kehidupan nyata.Terdapat beberapa permasalahan baik dalam segi peserta didik, guru maupun Rencana Pelaksanaan Pembelajaran (RPP). Dalam segi peserta didik peneliti menemukan permasalahan yaitu: (1) peserta didik kurang terbiasa untuk menggali sendiri pengetahuan dalam pembelajaran, hal ini terlihat ketika guru sedikit membedakan cara pengajuan pertanyaan kepada peserta didik, peserta didik kebingungan dalam menjawab pertanyaan yang diajukan oleh guru, (2) peserta didik kurang terlatih dalam bekerjasama di dalam kelompok, (3) peserta didik kurang bersemangat ketika proses pembelajaran berlangsung.

Masalah yang terlihat dalam sisi guru yaitu : (1) Guru belum menggunakan model pembelajaran yang sesuai dengan situasi, kondisi, dan karakteristik peserta didik, (2) Guru masih terkendala dalam pengenalan masalah-masalah nyata yang dekat dengan lingkungan peserta didik, (3) Guru belum optimal dalam mengorganisasikan peserta didik untuk belajar, ini terlihat pada proses pembelajaran guru kurang melukan tanya jawab terhadap materi/ masalah yang dibahas. (4) Guru belum terlihat membimbing peserta didik secara mandiri maupun kelompok. (5) Guru kurang mampu dalam manajemen kelas, ini terlihat ketika diskusi (menyajikan hasil LDK) kelas kurang kondusif serta peserta didik banyak yang keluar masuk. (6) Guru belum melakukan refleski atau evaluasi dalam permbelajaran. (7) Pembelajaran yang disajiakn guru masih terlihat pemisahan antar mata pelajaran, (8) Gurukurang menyajikan konsep dari berbagai muatan mata pelajaran, (9) Guru belum mengorganisasikan peserta didik untukbelajar,

Pada RPP peneliti menemukan permasalahan bahwa guru tidak mengembangkan RPP yang ada pada buku guru. Terlihat bahwa RPP yang digunakan sama persis dengan yang ada pada buku guru, yang mana seharusnya RPP itu dikembangkan dengan menggunakan model pembelajaran yang tepat sesuai dengan situasi, kondisi, dan karakteristik peserta didik.

Permasalahan di atas berdampak pada hasil belajar dan pencapaian peserta didik terhadap pembelajaran di kelas V SDN 15 Koto Kabun Kab. Pesisir Selatan. Hasil belajar beberapa peserta didik masih berada sebatas KBM bahkan ada pula yang berada dibawah KBM yang telah ditetapkan oleh sekolah. KBM yang telah ditetapkan adalah 70 . Berikut tabel hasil ujian tengah peserta didik kelas V SDN 15 Koto Kabun Kab. Pesisir Selatan semester 1 pada tahun ajaran 2020/2021.

Untuk mengatasi kondisi di atas, maka perlu diadakan perbaikan pada pelaksanaan pembelajaran demi hasil belajar peserta didik yang meningkat serta mengoptimalkan segala kemampuan peserta didik sebagaimana yang diharapkan pada kurikulum 2013. Salah satu 
caranya yang tepat dan sesuai dengan kurikulum 2013 ialah dengan pelaksanakan pembelajaran tematik terpadu dengan menggunakan model Problem Based Learning (PBL).

Penelitian ini dilaksanakan dengan tujuan untuk meningkatan hasil belajar peserta didik dalam pembelajaran tematik terpadu menggunakan model problem based learning (pbl) di kelas v sdn 15 koto kabun kabupaten pesisir selatan.

\section{Integrated Thematic Learning}

Pembelajaran tematik terpadu adalah pembelajaran yang di dalam pelaksanaannya guru mengajarkan beberapa mata pelajarandalamsatu tema terintegrasi dimana materimateri antar mata pelajaran yang berbeda tersebut saling berkaitan satu sama lain. Menurut Rusman (2015:139) "Pembelajaran tematik terpadu adalah pembelajaran yang dikemas dalam bentuk tema- tema berdasarkan muatan beberapa mata pelajaran yang dipadukan atau diintegrasikan". Pembelajaran tematik terpadu adalah pembelajaran yang membelajarkan peserta didik dalam tema-tema yang di dalamnya terdiri dari beberapa mata pelajaran yang berbeda yang saling berkaitan materi antara mata pelajaran yang termuat tersebut. Menurut Kemendikbud dalam jurnalnya Enik Setiyawati dan Dian Novita (2015: 85) "Pendekatan pembelajaran tematik terpadu merupakan pendekatan pembelajaran yang mengintegrasikan berbagai kompetensi dari mata pelajaran ke dalam tema". Sedangkan Majid (2014:86) mengemukakan pembelajaran tematik terpadu adalah:

1. pembelajaran yang bertitik tolak pada suatu tema sebagai pusat yang digunakan untuk memahami gejala- gejala, dan konsep- konsep baik yang berasal dari bidang studi yang bersangkutan maupun dari bidang studi lainnya, 2) suatu pembelajaran yang menghubungkan berbagai bidang studi yang menggambarkan kenyataan sebenarnya dan dalam rentang kemampuan dan perkembangan anak, 3) suatu cara untuk mengembangkan pengetahuan dan keterampilan anak, 4) menggabungkan suatu konsep dalam beberapa bidang studi yang berbeda dengan harapan anak akan belajar lebih baik danbermakna.

2. Pembelajaran tematik terapdu adalah pembelajaran terpadu yang menjadikan sebuah tema sebagai titik tolak dari beberapa matapelajaran yang materinya saling berkaitan antara satu materi satu dengan yang lain. Dimana dalam memahami materi yang disajikan, menggambarkan keadaan sebenarnya mengenai materi tersebut yang disesuaikan dengan kemampuan bepikir dan keterampilan anak.

Berdasarkan penjelasan di atas, pembelajaran tematik terpadu adalah pembelajaran yang membelajarkan peserta didik dalam tema- tema yang didalam tema tersebut terdapat mata pelajaran yang materi nya saling berkaitan antara materi satu dengan yang lain sehingga peserta didik dapat diarahkan langsung pada kenyataan sebenarnya mengenai materi yang diajarkan tersebut.

\section{Model Problem Based Learning}

Model pembelajaran adalah suatu kumpulan rencana-rencana (pola-pola) yang digunakan sebagai acuan dalam merancang pembelajaran di kelas (Ngalimun 2017:37). Kemudian, Joyce (dalam Ngalimun 2017:37) menyatakan bahwa "Earch model guides us as design instruction to helf students achieve various". Artinya, setiap model mengarahkan kita merancang pembelajaran untuk membantu peserta didik mencapai tujuan pembelajaran. Berdasarkan uraian di atas, model pembelajaran adalah kumpulan dari pola-pola penyajian materi pembelajaran demi tercapainya tujuan pembelajaran yang telah di direncanakan sejak awal perencanaan. Problem Based Learning (PBL) merupakan salah satu model yang dapat dilaksanakan dalam proses pembelajaran dengan kurikulum 2013. Menurut Hosnan (2014: 298) "Problem Based Learning (PBL) adalah model pembelajaran yang menggunakan masalah dunia nyata (autentik) yang tidak terstruktur (ill-structured) dan bersifat terbuka sebagai konteks bagi peserta didik untuk mengembangkan keterampilan menyelesaikan masalah dan berpikir kritis serta sekaligus membangun pengetahuan baru". 
Sedangkan menurut Faisal (2014: 76) mengatakan“ Problem Based Learning (PBL) merupakan suatu model pembelajaran yang menggunakan masalah dunia nyata sebagai fokus utama, kemudian mengkondisikan peserta didik berpikir kritis untuk mencari solusi terhadap permasalahan yang diajukan sehingga peserta didik memperoleh pengetahuan dan keterampilan yang esensial dari bahan pelajarannya". Menurut Duch (dalam Shoimin, 2014: 130) menyatakan bahwa "Problem Based Learning (PBL) adalah model pelajaran yang mencirikan adanya permasalahan nyata sebagai konteks untuk para peserta didik belajar berpikir kritis dan keterampilan memecahkan masalah serta memperoleh pengetahuan". Berdasarkan Pendapat beberapa para ahli diatas dapat disimpulkan bahwa Problem Based Learning (PBL) adalah suatu model pembelajaran yang menggunakan masalah dunia nyata sebagai konteks bagi peserta didik untuk belajar tentang keterampilan pemacahan masalah dan berpikir kritis untuk memperoleh pengetahuan dan belajar mengambil keputusan.

\section{METODE PENELITIAN}

Penelitian ini menggunakan jenis penelitian tindakan kelas (PTK). Menurut Arikunto (2008), penelitian tindakan kelas adalah penelitian yang dilakukan untuk mengkaji secara kegiatan belajar berupa sebuah tindakan, yang sengaja dimunculkan dan terjadi dalam sebuah kelas secara bersama. Penelitian tindakan kelas adalah kegiatan penelitian yang dilakukan dengan menelaah secara seksama dengan melakukan perlakuan yang sengaja dihadirkan dalam pembelajaran. Data dalam penelitian ini berupa data kualitatif dan kuantitatif yang diperoleh dari subjek yang diteliti, yakni guru dan peserta didik di kelas $\mathrm{V}$ SDN 15 Koto Kabun, kemudian data dalam penelitian ini dikumpulkan dengan menggunakan teknik observasi, dokumentasi dan tes. Penelitian ini dilaksanakan dengan menggunakan model siklus yang dikembangkan Kemmis (dalam Arikunto, 2008). Menurut Kemmins (dalam Arikunto, 2008:16). Penelitian tindakan kelas ini memiliki empat tahapan yang secara umumterdiri atas: perencanaan, pelaksanaan, pengamatan dan refleksi. Penelitian dilakukan menggunakan dua siklus. Setiap akhir siklus dilakukan tes hasil belajar. Alur penelitian tersebut dapat dilihat di gambar di bawah ini:

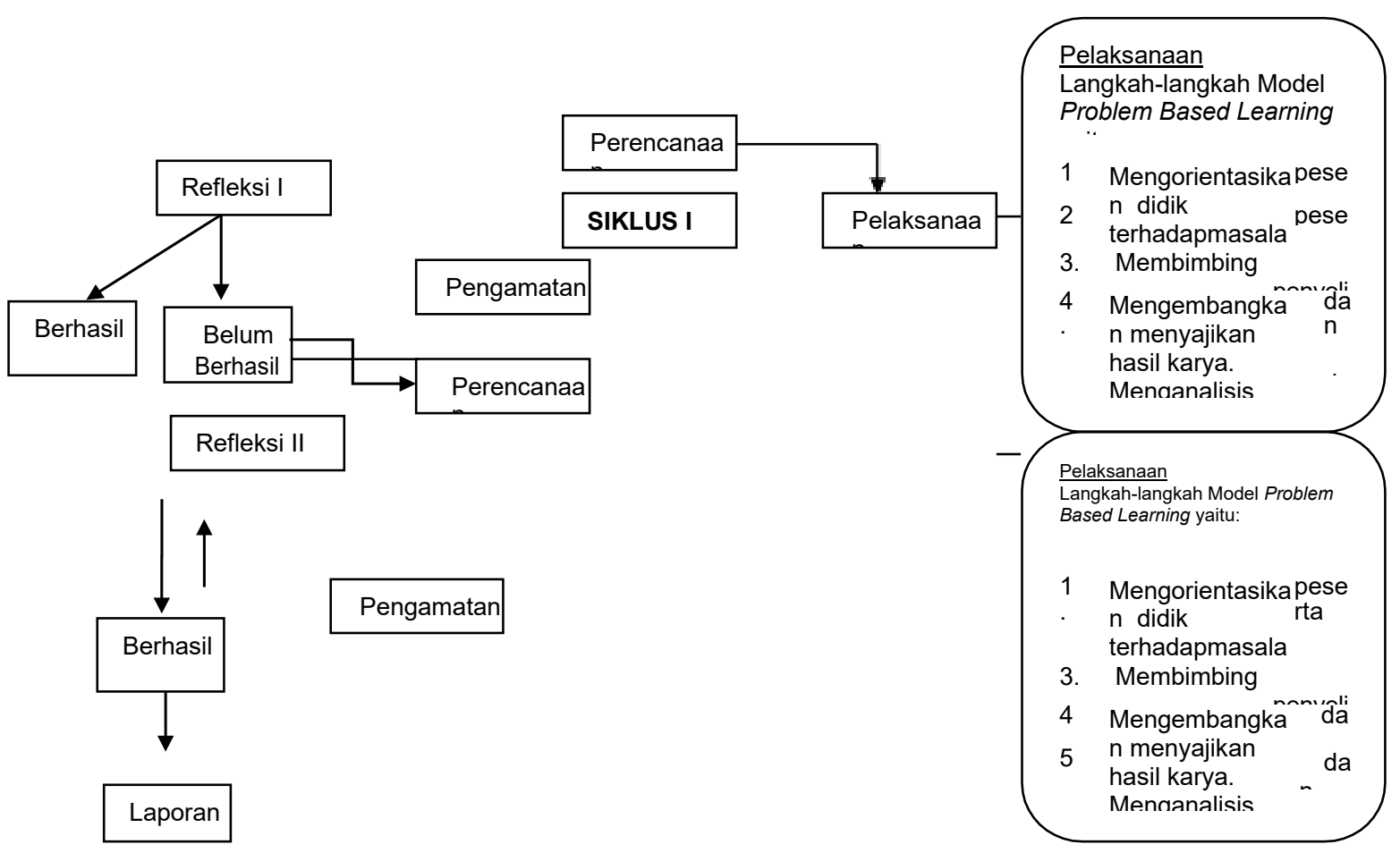

Gambar1. Alur Penelitian Penelitian Tindakan Kelas Model Kemis (dalam Arikunto, 2008:16) 


\section{HASIL DAN PEMBAHASAN}

Hasil penelitian yang dilihat dari aspek rencana pelaksanaan pembelajaran (RPP) pada siklus I pertemuan I memperoleh 23 skor dari skor maksimal 28 dengan persentase $82,14 \%$. Sedangkan pada siklus I pertemuan 2 memperoleh skor 25 dari 28 skor maksimal dengan persentase $92,85 \%$ sehingga rata-rata pada siklus I memperoleh skor $87,49 \%$ dengan kualifikasi Baik. Kemudian pada siklus II memperoleh 27 skor dari maksimal 28 persentase skor yang didapat yaitu 96,42\%. Dengan kualifikasi Amat Baik.

Selanjutnya dilihat dari aspek pelaksanaan pembelajarn yaituaspek guru pada siklus I pertemuan I adalah $71,42 \%$ dengan kualifikasi cukup meningkat pada siklus 1 pertemuan 2 menjadi $82,14 \%$ dengan kualifikasi baik sehingga memperoleh rata-rata $76,78 \%$ dengan kualifikasi cukup. Pada siklus II meningkat menjadi $92,85 \%$ dengan kualifikasi Amat Baik. Aspek peserta didik, pada siklus I pertemuan 1 adalah $71,42 \%$ dengan kualifikasi cukup meningkat, kemudian pada siklus I pertemuan 2 menjadi $82,14 \%$ kualifikasi baik sehingga memperoleh rata-rata $76,78 \%$ dengan kualifikasi cukup. Pada siklus II meningkat menjadi 92,85\% dengan kualifikasi Amat Baik.

Dan hasil belajar pelaksanaan pembelajaran pada siklus satu pertemuan 1, aspek sikap pada siklus I pertemuan I terdapat 5 orang peserta didik yang menonjolkan sikap negatif dan 3 orang peserta didik menonjolkan sikap positif. Aspek pengetahuan memperoleh rata-rata 68,16 dengan kategori baik. Pada siklus I pertemuan pertemuan 2 menjadi $81,40 \%$ dengan kategori sangat baik predikat A-. Rata-rata aspek pengetahuan pada siklus I adalah 74,78 kategori baik degan predikat B. Pada siklus II meningkat menjadi 91,76 kategori sangat baik predikat A. Aspek keterampilan pada siklus I pertemuan 1 memperoleh rata-rata 70,2 kategori baik dengan predikat B-. Pada siklus I pertemuan 2 memperoleh rata-rata 77 kategori baik predikat $\mathrm{B}+$. Rata-rata aspek keterampilan pada siklus I adalah 73,6 kategori baik dengan predikat B. Pada siklus II meningkat menjadi 81,33 kategori amat baik predikat. Untuk lebih jelasnya dapat dilihat pada grafik tersebut dapat dilihat dari tabel dibawah ini:

Tabel.1 Rekapitulasi Hasil Pengamatan Rencana Pelaksanaan Pembelajaran (RPP) , Aspek Guru, Aspek Peserta Didik, dan Hasil Pelaksanaan pembelajaran Tematik Terpadu dengan Model Problem Based Learning (PBL) di Kelas V SDN 15 Koto Kabun

\begin{tabular}{|c|c|c|c|c|c|c|c|}
\hline \multirow[b]{2}{*}{$\begin{array}{c}\text { Hasil } \\
\text { Pengamatan }\end{array}$} & \multicolumn{4}{|c|}{ Siklus I } & \multicolumn{3}{|c|}{ Siklus II } \\
\hline & P 1 & P2 & $\begin{array}{l}\text { Rata- } \\
\text { rata P1 } \\
\text { P2 }\end{array}$ & Kualifikasi & P 1 & $\begin{array}{l}\text { Rata- } \\
\text { rata }\end{array}$ & Kualifikasi \\
\hline 1. RPP & $82,14 \%$ & $92,85 \%$ & $87,49 \%$ & Baik (B) & $96,42 \%$ & $96,42 \%$ & $\begin{array}{c}\text { Amat } \\
\text { Baik (AB) }\end{array}$ \\
\hline \multirow[b]{2}{*}{ 2. Pelaksanaan } & \multicolumn{4}{|c|}{ Siklus I } & \multicolumn{3}{|c|}{ Siklus II } \\
\hline & P 1 & P 2 & $\begin{array}{l}\text { Rata- } \\
\text { rata P1 } \\
\text { P2 }\end{array}$ & Kualifikasi & P 1 & $\begin{array}{l}\text { Rata- } \\
\text { rata }\end{array}$ & Kualifikasi \\
\hline $\begin{array}{l}\text { a. Aspek } \\
\text { Guru }\end{array}$ & $71,42 \%$ & $82,14 \%$ & $76,78 \%$ & $\begin{array}{l}\text { Cukup } \\
\text { (C) }\end{array}$ & $92,85 \%$ & $92,85 \%$ & $\begin{array}{c}\text { Amat } \\
\text { Baik (AB) }\end{array}$ \\
\hline $\begin{array}{c}\text { b. Aspek } \\
\text { Peserta } \\
\text { Didik }\end{array}$ & $71,42 \%$ & $82,14 \%$ & $76,78 \%$ & $\begin{array}{l}\text { Cukup } \\
\text { (C) }\end{array}$ & $92,85 \%$ & $92,85 \%$ & $\begin{array}{c}\text { Amat } \\
\text { Baik (AB) }\end{array}$ \\
\hline \multirow[t]{3}{*}{ 3. Hasil Belajar } & \multicolumn{4}{|c|}{$\begin{array}{ll}\text { Siklus I } \\
\end{array}$} & \multicolumn{3}{|c|}{$\begin{array}{l}\text { Siklus II } \\
\end{array}$} \\
\hline & \multicolumn{3}{|c|}{ Rata-rata P1 P2 } & Prediket & \multirow{2}{*}{\multicolumn{2}{|c|}{$\frac{\text { Rata-rata }}{88,06}$}} & Prediket \\
\hline & & 74,19 & & Baik (B) & & & $\begin{array}{r}\text { Sangat } \\
\text { baik (A-) }\end{array}$ \\
\hline
\end{tabular}

\section{Pembahasan}

\section{Rencana pelaksanaan pembelajaran}

Perencanaan diperlukan agar pembelajaran tidak menyimpang dari tujuan yang akan dicapai. Perencanaan yang dimaksud dalam penelitian ini adalah Rencana Pelaksanaan 
Pembelajaran (RPP). Menurut Widyastono (2015:200) bahwa "RPP adalah rencana pembelajaran yang dikembangkan secara rinci dari suatu materi pokok atau tema tertenru yang mengacu pada silabus". Dengan demikian RPP merupakan langkah awal yang dilakukan guru sebelum kegiatan pembelajaran dilaksanakan sabagai acuan bagi guru untuk melaksanakan kegiatan pembelajaran agar lebih terarah dan berjalan secara efektif.

Dalam penelitian ini, RPP yang disusun sesuai dengan tahapan model Problem Based Learning menurut pendapat Faturahman (2016:116-117) yaitu: (1) mengorientasi peserta didik pada masalah, (1) mengorganisasi peserta didik untuk belajar, (3) Membimbing penyelidikan individual maupun kelompok, (4) mengembangkan dan menyajikan hasil karya, (5) menganalisis dan mengevaluasi proses pemecahanmasalah.

Pada siklus I pertemuan 1 dan 2 semua komponen rencana pembelajaran sudah terdapat dalam rencana pembelajaran, akan tetapi ada beberapa aspek RPP yang mesti diperbaiki yaitu: (1) pada pemilihan materi ajar belum ada kesesuaian antara materi ajar dengan lingkungan yang tersedia. Hal ini menunjukan kurangnya kesesuaian terhadap karakteristik PBL menurut Aris (2014) Authentic problems form the organizing focus for learning: masalah yang disajikan kepada siswa adalah masalah yang otentik yang dekat dengan lingkungan sehari-hari peserta didik sehingga peserta didik lebih mudah memahami masalah yang disajikan (2) Pada pengorganisasian materi ajar belum ada kesesuaian dengan alokasi waktu dan kemutakhiran (sesuai dengan perkembangan terakhir bidangnya). Akram (2008) meyatakan manajemen waktu adalah pemanfaatan waktu yang dimiliki untuk melakukan hal-hal yang dianggap penting yang telah tercatat dalam tabel kerja. Maka dari itu guru perlu lebih bisa memanajemen waktu agar semua langkah dalam rencana pelaksanaan pembelajaran yang telah dibuat dapat terlaksana dengan baik. (3) pada pemilihan sumber atau materi pembelajaran belum ada kesesuaian dengan lingkungan peserta didik, karena pembelajaran membahas rumah adat daerah kalimantan. (4) pada teknik pembelajaran belum sesuai dengan lingkungan sekolah karena pembahasan pembelajaran tidak menyangkut lingkungan yang ada disekitar sekolah. Sehingga rencana pembelajaran pada siklus 1 pertemuan 1 ini baru memperoleh 23 dari skor maksimal 28 dengan persentase $82,14 \%$. Sedangkan pada siklus I pertemuan 2 memperoleh skor 25 dari 28 skor maksimal dengan presentase $92,28 \%$ sehingga rata-rata pada Siklus I memperoleh skor $87,49 \%$.

\section{Pelaksanaan pembelajaran}

Berdasarkan perencanaan yang disusun, pelaksanaan proses pembelajaran disajikan dalam dua kali pertemuan. Siklus I dua kali pertemuan dan siklus II 1 pertemuan, setiap pertemuan dilaksanakan selama $5 \times 35$ menit. Dari hasil penelitian pelaksanaan proses pembelajaran tematik terpadu dengan model problem based Learning tema 8 (Lingkungan Sahabat Kita) di kelas V SDN 15 Koto Kabun, terungkap bahwa guru membuat perencanaan yang dimulai dengan membuat rancangan pembelajaran dalam bentuk Rencana Pelaksanaan Pembelajaran (RPP) sesuai dengan komponen RPP.

Selama pelaksanaan proses pembelajaran tematik terpadu dengan menggunakan model Problem Based Learning pada siklus I ditemukan hal-hal sebagai berikut:

Peserta didik tidak menanggapi aprersepsi dari guru. Selain itu juga peserta didik tidak mendengarkan tujuan pembelajaran yang disampaikan guru, hal ini menunjukan kurangnya kemampuan ketrampilan menjelaskanguru terhadap tujuan pembelajaran yang dipelajari saat itu. Majid (2014) menyatakan keterampilan menjelaskan merupakan keterampilan yang diperlukan guru dalam pembelajaran, karena ini termasuk kunci dalam pembelajaran.

Peserta didik tidak mendengarkan guru menjelaskan langkah kerja. Sehingga pada saat mengerjakan LDK nya masih banyak peserta didik yang kebingungan dalam mengerjakan LDK.Ini terjadi karena kurangnya motivasi peserta didik terhadap masalaha yang disajikan ada yang belum ditemui peserta didik dalam kehidupannya sehari-hari. Fauzia (2018: 42) mengemukakan: Ciri-ciri model problem based learning yaitu menerapkan pembelajaran yang kontekstual, masalah yang disajikan dapat memotivasi peserta didik 
untuk belajar, pembelajaran integritas yaitu pembelajaran termotivasi dengan masalah yang tidak terbatas, peserta didik terlibat secara aktif dalam pembelajaran, kolaborasi kerja, peserta didik memiliki berbagai keterampilan, pengalaman, dan berbagai konsep.

Peserta didik tidak mendengarkan guru menyampaikan tata cara yang dilakukan dalam menyampaikan laporan diskusi kelompok dan peserta didik yang lain tidak menanggapi atau mengevaluasi jawaban dari kelompok yang tampil.Sebaiknya untuk pembelajaran berikutnya guru harus bisa memperhatikan lagi kekurangan-kekurangan yang terjadi pada langkah ini. Sebagaimana dalam Kemendikbud (2014:28), "Tahap penyelidikan diikuti dengan menciptakan hasilkarya".

Peserta didik tidak ditanya kembali mengenai penjelasan yang telah disampikan. Selain itu peserta didik juga tidak menyimpulkan LDK yang telah dibahas bersama guru. Sehingga peserta didik tidak paham dengan kegiatan yang merekapelajari.

Peserta didik tidak melaksanakan kegiatan refleksi sebelum menyimpulkan pembelajaran. Sehingga peserta didik tidak dapat memaparkan keluhannya mengenai materi yang mesih belum mereka pahami.

Sedangkan Proses pembelajaran pada siklus II pembelajaran tematik terpadu tema 8 dengan menggunakan model problem based learning sudah terlaksana dengan baik. Dapat dilihat dari :

a. Guru sudah bisa memberikan apersepsi dan menjelaskan tujuan pembelajaran sebelum melaksanakanpembelajaran.

b. Guru sudah ada memberikan penjelasan mengenai langkah kerja LDK yang telah diberikan kepada peserta didik sehingga peserta didik tidak kebingungan lagi dalam mengerjakanLDK.

c. Guru sudah ada menyampaikan tata cara yang dilakukan dalam menyampaikan laporan diskusi kelompok dan meminta peserta didik yang lain tidak menanggapi atau mengevaluasi jawaban dari kelompok yang tampil. Sehingga kegiatan diskusi bisa berjalan denganbaik.

d. Guru sudah ada melakukan refleksi di akhirpembelajaran.

Berdasarkan data hasil pelaksanaan proses pembelajaran, maka hasil pengamatan aktivitas guru pada siklus I pertemuan 1 adalah $71,42 \%$ dengan kualifikasi cukup meningkat pada siklus I pertemuan 2 menjadi 82,14\% kualifikasi baik sehingga memperoleh rata-rata $76,78 \%$ dengan kualifikasi cukup. Pada siklus II meningkatmenjadi92,85\% dengan kualifikasi sangat baik. Sedangkan pengamatan aspek peserta didik siklus I pertemuan 1 adalah $71,42 \%$ dengan kualifikasi cukup meningkat pada siklus I pertemuan 2 menjadi $82,14 \%$ kualifikasi baik sehingga memperoleh rata-rata $76,78 \%$ dengan kualifikasi cukup. Pada siklus II meningkat menjadi 92,85\% dengan kualifikasi sangat baik.

\section{Hasil pelaksanaan pembelajaran}

Pelaksanaan proses pembelajaran yang sudah berjalan cukup baik juga berpengaruh pada penilaian hasil belajar peserta didik. Penilaian hasil belajar dilakukan dengan penilaian autentik. Hargreaves dkk dalam Majid (2014) mengemukakan "Penilaian autentik adalah sebuah bentuk penilaian yang mencerminkan hasil belajar yang sesungguhnya, dapat menggunakan berbagai cara atau bentuk, antara lain melalui penilaian proyek, portofolio, jurnal, demonstrasi, laporan tertulis, ceklis, dan petunjuk obsevasi". Penilaian autentik dalam proses pembelajaran dilihat dari aspek sikap, pengetahuan, dan keterampilan.

Pada siklus satu pertemuan 1 , aspek sikap pada siklus I pertemuan I terdapat 5 orang peserta didik yang menonjolkan sikap negatif dan 3 orang peserta didik menonjolkan sikap positif. Aspek pengetahuan memperoleh rata-rata 68,16 dengan kategoribaik predikatB-. Pada siklus I pertemuan pertemuan 2 menjadi 81,40 dengan kategori sangat baik predikat A-. Rata-rata aspek pengetahuan pada siklus I adalah 74,78 kategori baik degan predikat $B$. Pada siklus II meningkat menjadi 91,76 kategori sangat baik predikat $A$. Aspek keterampilan pada siklus I pertemuan 1 memperoleh rata-rata 70,2 kategori baik dengan predikat B-. Pada siklus I pertemuan 2 memperoleh rata-rata 77 kategori baik 
predikat $\mathrm{B}+$. Rata-rata aspek ketrampilan pada siklus I adalah 73,6 kategori baik dengan predikat B. Pada siklus II meningkat menjadi 81,33 kategori sangat baik predikat A-.

\section{SIMPULAN}

Dari paparan data hasil penelitian, dan pembahasan simpulan yang dapat kita ambil dari penelitian ini adalah sebagai berikut: (1) Perencanaan pembelajaran tematik di kelas $\mathrm{V}$ SD dengsan Model PBL disusun dalam bentuk RPP yang komponen penyusunnya terdiri dari kompetensi intu, kompetensi dasar, indikator, tujuan pembelajaran, materi pembelajran, proses pembelajaran, serta penilaian pembelajaran. Perencanaan pembelajaran dibuat secara kolabaoratif oleh peneliti dengan guru kelas V SDN 15 Koto Kabun. (2) Pelaksanaan pembelajaran tematik dengan PBL terdiri dari kegiatan awal pembelejaran, kegiatan inti, dan kegiatan akhir pembelajaran. Pelaksanaan pemebelajaran tematik dengan menggunakan PBL dilaksanakan dengan langkah-langkah: (a) orientasi siswa pada masalah, (b) mengorganisasi siswa untuk belajar, (c) membimbing penyelidikan individual dan kelompok, (d) mengemabngkan dan menyajikan hasil karya, (e) menganalisis dan mengevaluasi proses pemecahan masalah. (3) Hasil pengamatan dari pelaksanaan PBL siklus I pertemuan 1 menunjukkan bahwa pelaksanaan pembelajaran mendapatkan persentase yang diperoleh adalah $71,42 \%$. Pada siklus I pertemuan 2 persentase yang diperoleh adalah $82,14 \%$ sehingga pada siklus I memperoleh rata-rata $76,78 \%$ dengan kategori cukup (C). Sedangkan pada siklus II persentase yang diperoleh adalah $92,85 \%$ dengan kualifikasi amat baik (AB). Dari hal ini terlihat bahwa ada peningkatan pada tahap pelaksanaan mulai dari siklus I pertemuan 1, 2 sampai siklus II. Hasil belajar siswa dalam pembelajaran tematik di kelas V SDN 15 Koto Kabun dengan model Problem Based Learning (PBL), dapat meningkatkan hasil belajar peserta didik.

\section{DAFTAR PUSTAKA}

Akram, Muhammad. 2008. Manajemen Waktu. Yogyakarta: Pustaka Marwa. Amir, Taufiq. 2010. Inovasi Pendidikan Melalui Problem Based Learning.Jakarta: Prenada Media Grup

Arikunto, S. 2008. ProsedurPenelitianS uatuk Pendekatan Praktik. Jakarta: Rineka Karya.

EnikSetiyawatidan Dian Novita (2015).Peningkatan Kemampuan Metakogniti fSiswa Melalui Pembelajaran Tematik Siswa Kelas V di MI Manbaul Hikmah Kediri, 4, 83-94.

Faisal. 2014. Sukses Mengawal Kurikulum 2013 di SD (Teori dan Aplikasi).Yogyakarta: Diandra Creative

Faturrahman, Muhammad. 2016. Model-model Pembelajaran Inovatif. Jogjakarta: Ar-ruzz Media.

Fauziyah, Djaelani, dkk. 2018. Pengaruh Lingkungan Kerja Serta Keselamatan Dan Kesehatan Kerja Terhadap Produktivitas Kerja Karyawan. Jurnal Riset Manajemen.

Hosnan. (2014). Pendekatan Sauntifik dan Kontekstual dalam Pembelajaran Abad21. Bogor: Ghalia Indonesia.

Kemendikbud. 2014. Materi Pelatihan Guru Implementasi Kurikulum 2013.Jakarta: Kemendikbud

Majid, Abdul. (2014). Pembelajaran Tematik Terpadu.Bandung:PT Remaja Rosdakarya

Ngalimun. (2017). Strategi Pembelajaran. Yogyakarta: Parama Ilmu. Permendikbud. 2013. Kerangka Dasar Dan Struktur Kurikulum Sekolah

Rusman. (2015). Model-Model Pembelajaran Pengembangan Profesionalisme Guru. Jakarta: RajaGrafindo Persada

Shoimin, Aris. (2014). 68 Model Pembelajaran Inovatif dalam Kurikulum 2013. Jogjakarta: Aruzz Media.

Widiastono, Herry.(2015). PengembanganKurikulum di Era Otonomi Daerah.Jakarta: BumiAksara

Yarsina, F. (2016). Peningkatan Proses Pembelajaran Tematik Menggunakan Model Bamboo Dancing Di Sekolah Dasar. Jurnal Inovasi Pembelajaran SD, 1, 1-15. Retrieved from http://ejournal.unp.ac.id/index.php/pd 